\title{
Characteristics and Spatial Influencing Factors of Natural Regeneration within Aquaculture ponds in a Mangrove Forest
}

kun xin ( $\nabla$ xin_kun@126.com )

Research Institute of Tropical Forestry Chinese Academy of Forestry https://orcid.org/0000-0003-17497634

\section{Nong Sheng}

Research Institute of Tropical Forestry Chinese Academy of Forestry

Yanmei Xiong

Research Institute of Tropical Forestry Chinese Academy of Forestry

\section{Zhongmao Jiang}

Research Institute of Tropical Forestry Chinese Academy of Forestry

\section{Yun Zhang}

Research Institute of Tropical Forestry Chinese Academy of Forestry

\section{Baowen Liao}

Research Institute of Tropical Forestry Chinese Academy of Forestry

\section{Research Article}

Keywords: Mangrove forest, Aquaculture ponds, Natural regeneration, Spacial influencing factors, Community structure

Posted Date: June 16th, 2021

DOI: https://doi.org/10.21203/rs.3.rs-625932/v1

License: (a) (1) This work is licensed under a Creative Commons Attribution 4.0 International License. Read Full License 
5 Kun Xin*, Nong Sheng, Yanmei Xiong, Zhongmao Jiang, Yun Zhang, Baowen Liao 6 


\section{ABSTRACT}

Regeneration is an important component of community succession and understanding regeneration dynamics is essential for forest protection and recovery management. Mangroves are distributed along coastlines and this unique habitat has resulted in very different regeneration process. This study took Dongzhaigang mangrove forest in Hainan, China as the study area, considered the 10 years regeneration process in 8 abandoned aquaculture ponds, and the spatial factors that influence the regeneration process are analyzed. The objectives were to: a) investigate the natural dynamics of the mangrove regeneration process in abandoned ponds, b) determine the main spatial factors affecting the natural regeneration process. The results showed that the number of species and individuals showed a tendency to initially rise and then decline, with the maximum occurring at $6-$ 8 years. The results of a diversity index showed an initial rise, with stabilization then occurring over a 8 year period. Aegiceras corniculatum and Sonneratia apetala were typical pioneer mangrove species in the study area, while Bruguiera sexangula and Kandelia obovata were representative species of late regeneration period. Spatial factors, including pond area and shape, relative elevation, distance to a tidal creek and surrounding trees area played important roles in the regeneration of mangrove in ponds. Finally, the study considered the current situation regarding mangrove restoration in China and suggested that natural regeneration of mangroves is a good management option.

\section{Keywords}

Mangrove forest

Aquaculture ponds

Natural regeneration

Spacial influencing factors

Community structure 


\section{Introduction.}

With a distribution across estuary and coastal areas in the tropics and subtropics, mangrove forest is critically important for the maintenance of biodiversity (AwuorOwuor et al., 2019). In recent decades, mangrove forests have been seriously damaged worldwide (Menéndez et al., 2018) due to aquaculture and urbanization, rising sea levels, changes in hydrologic processes, and so on. Among which aquaculture ponds is considered to be the most serious threaten. Since 1980s, the prawn industry has boomed in Southeast Asian countries, with more than 1.2 million $\mathrm{hm}^{2}$ of mangroves has been converted into fish ponds(Richards \& Friess, 2016). 64\% of mangrove destruction is due to pond farming in Thailand(Matsui et al., 2010). The study based on remote sensing data showed that more than $50 \%$ of the global decline in mangrove area is due to pond farming (Kuenzer et al., 2011). This situation is even more prominent in China. During 1980-2000, the total occupied area of mangroves in Guangdong province of China reached $7912.2 \mathrm{hm}^{2}$, of which $7767.5 \mathrm{hm}^{2}(98.2 \%)$ were used for fish ponds, and a total of $12,923.7 \mathrm{hm}^{2}$ of mangroves disappeared in China, of which 97.6\% disappeared for building fish ponds (Department of Forest Resources Management, State Forestry Administration, 2002). Returning ponds to mangrove is the most important path of mangrove protection and restoration in China. Artificial planting is the main method of mangrove restoration at present, however, the resulting problems such as species monogamy, habitat damage and alien plant diffusion have been widely concerned (Bosire et al., 2008).

Natural regeneration is considered to be a better way for improving biodiversity in contrast to artificial restoration(Levis et al., 2019), however less study has been conducted on the process of mangrove natural restoration in abandoned ponds. Forestry studies showed that forest gaps are an important feature of natural forests and are thought to contribute to species diversity by providing opportunities for niche differentiation in modes of regeneration (Richards et al., 2011) . Theoretically, when a gap formed, adjacent trees are able to quickly capture the vacant growing space and close the gap (Yamamoto, 2000). The gap phase is considered to be the most important stage of the natural forest regeneration process (Connell et al., 1985). The aquaculture ponds within the mangrove forest are supposed to be the forest gap. When ponds were abandoned and tidal process returned to normal, the surrounding mangrove plant propagators (including propagules and seeds) will drift into the abandoned ponds along the tidal creek, and begin to settle, 
grow and develop into mangrove plant communities(Stevenson et al., 1999). Mangroves show considerable regeneration ability in natural disturbances (storms, hurricanes), suggest pioneer-phase characteristics(Alongi D M, 2008). The factors of soil and water characters that influencing mangrove regeneration were discussed(Yanmei X., et al., 2021), however, very few studies have focused on the natural regeneration of mangroves in pond rehabilitation and the spatial factors that influence this process remain unclear.

In this study, we surveyed natural regeneration process within 8 ponds 10 years after being abandoned in Dongzhai Harbor of Hainan, and spatial factors that affected the community structures were analyzed. We aimed to tell : (I) How long does a regeneration process take from abandoned ponds to stable mangroves community; (II ) How does mangrove composition change during the first 10-year natural regeneration period in ponds of mangrove? (III) How do ponds spatial properties affect the composition of the regeneration community?

\section{Materials and methods}

\subsection{Study area}

The Dongzhaigang mangrove wetlands reserve has the most continuous distribution of mangrove forest in China (Kun Xin et al., 2018) and is located in the northeastern part of the Hainan Islands $\left(\mathrm{N} 19^{\circ} 51^{\prime}-20^{\circ} 01^{\prime}\right.$, E $\left.110^{\circ} 30^{\prime}-110^{\circ} 37^{\prime}\right)$. The mean annual air temperature is $23.5{ }^{\circ} \mathrm{C}$, with a maximum of $28.4{ }^{\circ} \mathrm{C}$ in July and a minimum of $17.1{ }^{\circ} \mathrm{C}$ in January. The mean annual rainfall is $1676 \mathrm{~mm}$, with a rainy season between May and October. The tides are irregularly semi-diurnal, with an average tidal range of about $0.89 \mathrm{~m}$. The reserve covers an area of $33.38 \mathrm{~km}^{2}$ and contains 36 different mangrove species, among Rhizophora stylosa, Kandelia obovata, Aegiceras corniculatum and Bruguiera sexangula are common species. The rich biodiversity of the Dongzhaigang mangrove wetlands reserve makes it the most important mangrove area in China.

Since 1980 's, around 160 ha mangroves were transformed into aquaculture ponds within the reserve. While in recent decades, protection and restoration of mangrove forest has getting more attentions, aquaculture in mangroves is forbidden and ponds within reserve were abandoned. To accelerate vegetation restoration, artificial planting was the common way, while many adverse impacts were noticed, such as limited biodiversity, introduced fast growing species, existing 
habitat destroyed by large machines. Natural regeneration were more and more recommended by scholars, while little of the natural regeneration process in this area was known.

\subsection{Sample plots}

Eight natural regeneration ponds which were abandoned in the year 2009 were selected for study plot (see Fig.1). Google Earth ${ }^{\circledR}$ (http://earth.google.com) image of eight ponds in the year of 2011, 2013, 2015,2017 and 2019 are listed in Figure 2. The Arcgis 10.0 software (Esri, Redlands, CA, USA) was used to calculate ponds and mangrove covered area.

\subsection{Plant composition investigation, Biomass and biodiversity calculation}

The investigation sites were sampled in 2011. Three plots of $100 \mathrm{~m}^{2}$ were set in each ponds for plant investigation. In each plot, the ground trunk diameter and tree height of each mangrove plant with ground trunk diameter $>1 \mathrm{~cm}$ and height $>0.3 \mathrm{~m}$ were measured. The species composition, height, diameter at roots ( $3 \mathrm{~cm}$ above ground) and crown diameter (average of two vertical axis) were measured and recorded. The plant investigation were conducted in the year 2011, 2013,2015, 2017 and 2019 respectively.

Then mean(W) of 2 biomass models(Jin et al., 2012) from Bruguiera gymnorrhiza were used to calculate mangrove biomass.

$$
\begin{gathered}
\mathrm{W}_{1}=0.915(\mathrm{D} \times \mathrm{H})^{0.9762} \\
\mathrm{~W}_{2}=0.908\left(\mathrm{D}^{2} \times \mathrm{C}\right)^{0.4212} \\
\mathrm{~W}=\left(\mathrm{W}_{1}+\mathrm{W}_{2}\right) / 2
\end{gathered}
$$

Ground diameter (D), height $(\mathrm{H})$ and crown diameter $(\mathrm{C})$ were measured in sample plots. $H^{\prime}$ '(Shannon-wiener Index), which indicates distance-independent plant composition diversity, the higher the Shannon Index, the higher the community biodiversity, and $E$ (Pielou index), which indicates the spatial distribution uniformity of plants, the greater the Pielou Index is, the more uniform the distribution of individual number is and the higher the biodiversity is. In this study, these two indices were used to analyze the structure of communities(Lei \& Tang, 2002).

$$
\mathrm{H}^{\prime}=-\sum_{i=1}^{s} P_{i} \ln P_{i}
$$


$P_{i}$ is $N i / N, N i$ is abundance of species $i, N$ is total individual number; $H \max =\ln S, \mathrm{~S}$ is species

124

abundance.

\subsection{Important spatial factors measurement}

in ArcGIS platform, according to the image of the aquaculture pond in 2009, the area and perimeter of each pond were measured, and area to perimeter ratio were calculated.

Elevation of each pond and the elevation of local mean sea level were measured with Real Time Kinematic (RTK) global navigation satellite receivers (G970II Pro, UniStrong, Beijing China) in the CGCS 2000 coordinate system. RTK is a highly precise technique, yielding data with an accuracy of one inch. 13 points of each ponds were measured (points selecting methods see fig3), and average elevation of 8 ponds were calculated.

Tidal process is very important for mangrove restoration and tidal creeks are the important channels of tides. There are two natural tidal creeks in the east and west of ponds distribution area. In ArcGIS10.0 (Esri, Redlands, CA, USA), the center mass coordinate of each aquaculture pond was defined, and the average vertical distance from the center point to two tidal creek boundary was measured, namely, the distance to tidal creek.

Aquaculture ponds dug within mangroves are surrounded by native mature mangroves. 100-meter buffer zone were made from the boundary of each aquaculture pond, and the area of adult mangroves in the buffer zone were calculated in ArcGIS.

\subsection{Data Analysis Methods}

The differences of community dominated by different mangrove species were determined by one-way ANOVA. The relationships between mangroves composition and its potential influencing factors were determined by Pearson correlations. Statistical analyses and hierarchal clustering analyses were conducted using $R$ statistical software at a significance level of 0.05 (R Core Team, 2014). 


\section{Results}

\subsection{Natural regeneration rate}

150

The results showed that after 10 years natural regeneration, $74.88 \%$ of ponds returned to mangroves forest on average, among which $\mathrm{B}$ pond regenerated $97.15 \%$ and $\mathrm{F}$ pond $37.25 \%$, which was the maximum and minimum. The rate of mangroves increasing within 8 ponds could be seen in figure 4.

By comparing areas in different years, it showed that the average increasing rate was $6.89 \%$ per year, while except the pond E, which increased quickly in 2019, the most rapid increasing of mangroves happened during the year of 2013 to 2015 , the time about 4-6 years after ponds being abandoned (see Fig. 4), .

Hierarchal Clustering Analyses (see Fig. 5) showed that the regeneration rate between $\mathrm{A}$ and $\mathrm{H}$ pond has the greatest similarity, followed by $\mathrm{C}$ and $\mathrm{E}$ pond, while similarity between $\mathrm{F}$ pond and other ponds is the least.

\subsection{Community composition and structure}

It was found that the number of species increased over the first several years, reaching the average of 5.58 species in the sixth year, and then slowly declined before stabilizing at 4 species in the 8 to 10 year. Except pond $\mathrm{F}$ and $\mathrm{G}$, which the peak of species number appeared in 2017 and 2019, the peak number of other 6 ponds appeared in the year 2015, and the maximum is 9 species in pond A(see figure 6).

The average density of plants of 8 ponds (including saplings over $30 \mathrm{~cm}$ ) increased from $24.8 / 100$ $\mathrm{m}^{2}$ in 2011 and reached peak at $37 / 100 \mathrm{~m}^{2}$ in 2013, 4 years after being abandoned (see figure 6), then dropped slowly to $26.8 / 100 \mathrm{~m}^{2}$ in $2015,23.9 / 100 \mathrm{~m}^{2}$ in 2017 and $21.6 / 100 \mathrm{~m}^{2}$ in 2019 . The peak density of plant appeared in pond B, which is $50.5 / 100 \mathrm{~m}^{2}$ in the year 2013 .

The Shannon index of 8 ponds is 1.23 on average in the year 2011, and continually increased to 1.31 in 2013 and 1.39 in 2015, until they reached the peak and stabilized at 1.48 in the year 2017. Pond $\mathrm{B}$ and pond $\mathrm{H}$ took the top two and pond $\mathrm{F}$ and pond $\mathrm{G}$ were the last two. 
The Pielou index increased from 0.1633 in 2011 to 0.1951 in 2017, and stabilized at 0.1950. Same as Shannon index, pond $\mathrm{B}$ and pond $\mathrm{H}$ took the top two and pond $\mathrm{F}$ and pond $\mathrm{G}$ were the last two (see figure 6).

According to percentage of each species in different years(see figure 7), we can see that Aegiceras corniculatum was present in $63.3 \%$ in the year of 2011 which decreased to $40 \%$ during $2013-2015$, and 30\% during 2017-2019, indicating that Aegiceras corniculatum is pioneer specie with a strong ability to spread at the beginning of mangrove natural regeneration . In contrast, the abundance of Rhizophora styolsa and Kandelia obovata increased respectively from $8.4 \%$ to $33.3 \%$ and $3.0 \%$ to $8.7 \%$ during the same periods, meaning that with a change of environment, these species began to adapt to the changes. The introduced species, Sonneratia apetala, experienced an increasing from $6.8 \%$ in 2011 to $14.4 \%$ in 2015 , and followed by a decreasing to $9.5 \%$ in 2019 , indicating that Sonneratia apetala is a pioneer species in the mangrove regeneration processing, and with the stability of the community structure, its importance in the community gradually decreased. Species such as Lumnitzera racemosa and Acanthus ilicifolius appeared only in 2015, meaning that the seeds of these species can reach ponds area, but are less competitive than the other species.

\subsection{Influence of important spatial factors}

Distance to tidal creeks (see Tab.1) showed extremely significant correlated $(\mathrm{p}<0.01)$ to density of plants ( $\left.\mathrm{R}^{2}=0.915\right)$, species number $\left(\mathrm{R}^{2}=0.862\right)$ and biomass $\left(\mathrm{R}^{2}=0.915\right)$, and significant correlated $(\mathrm{p}<0.05)$ to indices $\left(\mathrm{R}^{2}=0.564\right.$ and $\left.\mathrm{R}^{2}=0.485\right)$. Relative elevation and adult tree area were significant correlated $(\mathrm{p}<0.05)$ to density of plants $\left(\mathrm{R}^{2}=0.915\right.$ and $\left.\mathrm{R}^{2}=0.915\right)$, and significant correlated $(\mathrm{p}<0.05)$ to species number $\left(\mathrm{R}^{2}=0.862\right.$ and $\left.\mathrm{R}^{2}=0.983\right)$ and biomass $\left(\mathrm{R}^{2}=0.975\right.$ and $\mathrm{R}^{2}=0.909$ ), while no related to indices. Ponds area and area/perimeter showed negative correlation $(\mathrm{p}<0.05)$ to density of plants $\left(\mathrm{R}^{2}=0.342\right.$ and $\left.\mathrm{R}^{2}=0.299\right)$, and no relation to species number, biomass and indices.

\section{Discussion}

The regeneration rate after 10 years of natural restoration showed that more than $70 \%$ of the cultivation ponds have been restored to mangroves(see Fig.4). That means mangrove community 
can be regenerated by natural processing in the aquaculture ponds that located in mangrove forest.

During the 10 years of natural regeneration of mangroves, a total of 10 species of mangrove plants appeared in the cultivation ponds (see Fig.7). Among them, there were 6 common mangrove plants, including Aegiceras corniculatum, Rhizophora stylosa, Bruguiera gymnorrhiza, Bruguiera sexangula, Kenaelia obovata and Avicennia marina, which are consistent with the surrounding mangrove communities. What is noteworthy is that the max percentage of Sonneratia apetala in the regeneration process was $15 \%$, but there were no surrounding parent trees of S. apetala, meaning that it has strong diffusion ability.

The mean of Shannon diversity and Pielou index of the 8 ponds were 1.5 and 1.9, and kept stable since 2017(see Fig.6). It mean that the stable and original community structure can be restored by natural regeneration. Mangrove restoration projects are currently underway in China, there are about $18,800 \mathrm{hm}^{2}$ of mangrove forest will be restored in the period of 2021-2025 (Department of Ecological Restoration, 2020). To achieve the aim on time, many managers prefer artificial planting, introduced mangrove species, including Sonneratia apetala (from the Bay of Bengal) and Laguncularia racemosa (from the Gulf of Mexico) (Liu et al., 2011), with fast growing and high survival rate were used. The planting of these species over a large area has led to a decline of biodiversity (Han et al., 2010; Ren et al., 2009). In this study, we found that natural regeneration occurred in all ponds, and the species diversity was very high and community composition was very similar to that of primary forest. So, within aquaculture ponds in mangrove area, natural regeneration is highly recommended in future mangrove restoration projects.

The cluster analysis of the regeneration process within 8 ponds showed that the ponds with similar area and shapes had the more similar regeneration process (see Fig.5), and smaller area and area/perimeter were more conducive to natural restoration in ponds((see Tab.1), which indicated that the natural regeneration process of the mangrove forests was affected by the area and shape of the ponds. The area and shape of different ponds can affect seed germination and seedling settlement through different amount of seed interception, water exchange frequency and soil flooding time(Mcnab et al., 2020; Saraiva et al., 2020), so as to affect the natural regeneration process of aquaculture ponds. 
Mangrove habitats are within coastal zones, and seed dispersal is largely due to transport by tidal creeks. The results showed that the distance to tidal creeks were important for mangrove community structure (see Tab.1). Seed dispersal is at the core of the Janzen Connell hypothesis that explains the high diversity of tree species in tropical forests (Fox et al., 1976; Hyatt et al., 2003). Water are considered to be important media for the transmission of seeds (Andresen et al., 2005; Rotundo et al., 2005). Species such as A. corniculatum, with a huge floating seed capacity, have an absolute advantage during first years (see Fig. 7). Its seeds are carried by tidal water and reach open spaces, becoming retained in ponds, while those species with seeds that have less ability to float, such as B. sexangula, K. obovata, and Rhizophora stylosa, would have fewer opportunities to occupy ponds at the very beginning of the regeneration process (see Fig. 7).

The relative elevation and adult tree area have a significant effect on community structure during the regeneration process (see Table 1). Within-gap heterogeneity should be taken into account when considering the factors that affect natural regeneration (Gray et al., 1996). Heterogeneity may be caused by many factors (Chen et al., 2005), such as micro-topography, soil physical-chemical characteristics, and shelter by the surrounding forest. In a mangrove forest, the ponds with the greatest difference in topographical elevation (height difference) will trap most mangrove seeds, and therefore relative elevation had the greatest influence on community composition at the very beginning of the regeneration process (see Fig.6). As the plants grow, the ground flattens out, and the effect of relative elevation gradually decreases.

\section{Conclusion}

By 10 years monitoring, we concluded that it would take about 6-8 years to generate naturally from an abandoned aquaculture pond to a stable mangrove plant community. Although compared to artificial forest, the natural regeneration process requires longer time, less disturbance and richer biodiversity are expected.

Aegiceras corniculatum is an important species in the whole regeneration processing. It is not only the main constituent species, but also the most important pioneer species, played an important role in early settlement and habitat modification. While mangrove species, such as Rhizophora styolsa and Kandelia obovata, with less propagules, are highly competitive and therefore occupy an 
important proportion in the final stable communities. The introduced species, Sonneratia apetala, is also a pioneer species, the invasion risks should be taken into consideration in future pond rehabilitation.

There are many factors that influence the regeneration process, which should be taken into account. Nevertheless, this study demonstrated the importance of tidal creeks around ponds. A perfect tidal creek system is indispensable for successful natural regeneration within ponds.

\section{Acknowledgment}

The study was supported by Grant No.CAFYBB2020SY020 from

Chinese Academy of Forestry and No.31660126 and No. 41676080 from the Natural Science

Foundation of China. And we thank International Science Editing

( http://www.internationalscienceediting.com ) for editing this manuscript.

\section{References}

Alongi D M(2008) . Mangrove forests: Resilience, protection from tsunamis, and responses to global climate change. Estuarine Coastal \& Shelf Science, 2008, 76(1):1-13.

AwuorOwuor, M., Mulwa, R., Otieno, P., Icely, J., \& A.Newton. (2019). Valuing mangrove biodiversity and ecosystem services: A deliberative choice experiment in Mida Creek, Kenya. Ecosystem Services, 40, 1010-1020.

Bosire, J.O., Dahdouh-Guebas, F., Walton, M., Crona, B.I., Lewis, R.R., Field, C., Kairo, J. G., Koedam, N., (2008). Functionality of restored mangroves: a review. Aquat. Bot. 89, 251-259.

Čater, M., Diaci, J., \& Roženbergar, D. (2014). Gap size and position inflfluence variable response of Fagus sylvatica L. and Abies alba Mill. For. Ecol. Manage, 325.

Chen, S., Song, A., \& Li, Z. (2005). Research advance in response of forest seedling regeneration to light environmental heterogeneity. Chinese Journal of Applied Ecology, 16(2), 365-370.

Collins, B. S., \& Battaglia, L. L. (2002). Microenvironmental heterogeneity and Quercus michauxii regeneration in experimental gaps. Forest Ecology \& Management, 155(1), 279-290.

Connell, \& Joseph, H. (1985). The Ecology of Natural Disturbance and Patch Dynamics || Disturbance and Patch Dynamics of Subtidal Marine Animals on Hard Substrata. 125-151.

Fox, \& J., E. D. (1976). Constraints on the natural regeneration of tropical moist forest. Forest Ecology \& Management, 1, 37-65.

Gagnon, J. L., Jokela, E. J., Moser, W. K., \& Huber, D. A. (2003). Dynamics of artificial regeneration in gaps within a longleaf pine flatwoods ecosystem. Forest Ecology \& Management, 172(2-3), 133-144.

Gray, Andrew, N., Spies, Thomas, \& A. (1996). Gap size, within-gap position and canopy structure effects on conifer seedling establishment. Journal of Ecology.34(5),241-247 
Han, S. M., Ni-Ya, L. I., Ping, H. E., Zhong, C. R., \& Yang, Y. (2010). Photosynthetic characteristics of introduced and indigenous mangrove seedlings in China. Acta Botanica Boreali-Occidentalia Sinica, 30(8), 1667-1674.

Lewis, R.R., Brown, B., Flynn, L.L..(2019). Methods and criteria for successful mangrove forest rehabilitation. In: Perillo, G.M.E., Wolanski, E., Cahoon, D.R., Hopkinson, C.S. (Eds.), Coastal Wetlands (second edition): An Integrated and Ecosystem Approach, 24, pp. 863-887.

Liu, S. C., Duan, W. B., Feng, J., \& Han, S. Z. (2011). [Effects of forest gap on tree species regeneration and diversity of mixed broadleaved Korean pine forest in Xiaoxing'an Mountains]. Chinese Journal of Applied Ecology, 22(6), 1381-1388.

Mcnab, W. H., Kilgo, J. C., Blake, J. I., \& Zarnoch, S. J. (2020). Effect of gap size on composition and structure of regeneration 19 years after harvest in a southeastern bottomland forest, USA. Canadian Journal of Forest Research. 51(1), 1-10

Menéndez, P., Losada, I. J., Beck, M. W., Torres-Ortega, S., Espejo, A., Narayan, S., \& Lange, G.-M. (2018). Valuing the protection services of mangroves at national scale: The Philippines. Ecosystem Services, 34, 24-36.

Nicotra, Adrienne, B., Chazdon, \& Robin, L. (1999). Spatial heterogeneity of light and woody seedling regeneration in tropical wet forests. Ecology. 80(6), 1908-1926.

Ren, H., Lu, H., Shen, W., Huang, C., Guo, Q., Li, Z. A., \& Jian, S. (2009). Sonneratia apetala Buch.Ham in the mangrove ecosystems of China: An invasive species or restoration species? Ecological Engineering, 35(8), 1243-1248

Richards, J. D., \& Hart, J. L. (2011). Canopy gap dynamics and development patterns in secondary Quercus stands on the Cumberland Plateau, Alabama, USA. Forest Ecology \& Management, 262(12), 2229-2239.

Rotundo, J. L., \& Aguiar, M. R. (2005). Litter effects on plant regeneration in arid lands: a complex balance between seed retention, seed longevity and soil-seed contact. Journal of Ecology, 93.

Saraiva, M., Ferreira, M. D. P., Cunha, D. A. D., Daniel, L. P., \& Pires, G. F. (2020). Forest regeneration in the Brazilian Amazon: Public policies and economic conditions. Journal of Cleaner Production, 269.

Stevenson, N.J., Lewis, R.R., Burbridge, P.R., Streever, W.J. (1999). Disused shrimp ponds and angrove rehabilitation. In: An International Perspective on Wetland Rehabilitation. Kluwer Academic Publishers, the Netherlands, pp. 277-297.

Xin, K., Yan, K., Gao, C., Li, Z., \& . . (2018). Carbon storage and its influencing factors in Hainan Dongzhangang mangrove wetlands. Marine and Freshwater Research, 69 (5), 771-785.

Yamamoto, S. I. (2000). Forest gap dynamics and tree regeneration. Journal of Forest Research, 5(4), 223-229.

Yanmei X., Zhongmao J., Kun X., Baowen L., Yujun C., Mei L. , Hao G. , Yanzhe X., Xin Z., Chunlan Z. (2021). Factors influencing mangrove forest recruitment in rehabilitated aquaculture ponds. Ecological engineering, 168, 10272

Zeng, Q. Y., Liu, S. Q., Huang, J. J., Ji-Ping, L. I., Han, W. D., Zhou, Y. M., \& University, G. O. (2014). Border tree characteristics of seriously disturbed mangrove gap in Techeng Island. Journal of Fujian College of Forestry. 
All data are transparency.

339 Not applicable.

340 Consent to Participate (Ethics)

341 All participant consent to participate.

342 Consent to Publish (Ethics)

343 Manuscript is approved by all authors for publication.

$344 \quad$ Plant Reproducibility

$345 \quad$ Not applicable.

Clinical Trials Registration

$347 \quad$ Not applicable.

349 K. Xin,N.Sheng and BW. Liao contributed to the conception of the study;

$350 \quad$ N.Sheng and ZM.Jiang performed the fields investigation;

351 K.Xin and YM.Xiong contributed significantly to sample plots selection and manuscript

352 preparation;

353 N.Sheng and K.Xin performed the data analyses and wrote the manuscript;

354 YM.Xiong and ZM.Jiang helped perform the analysis with constructive discussions.

356 No conflict of interest exits in the submission of this manuscript.

$357 \quad$ Funding

358 The study was supported by Grant No.CAFYBB2020SY020 from

359 Chinese Academy of Forestry and No.31660126 and No. 41676080 from the Natural Science 360 Foundation of China. 


\section{Figures}

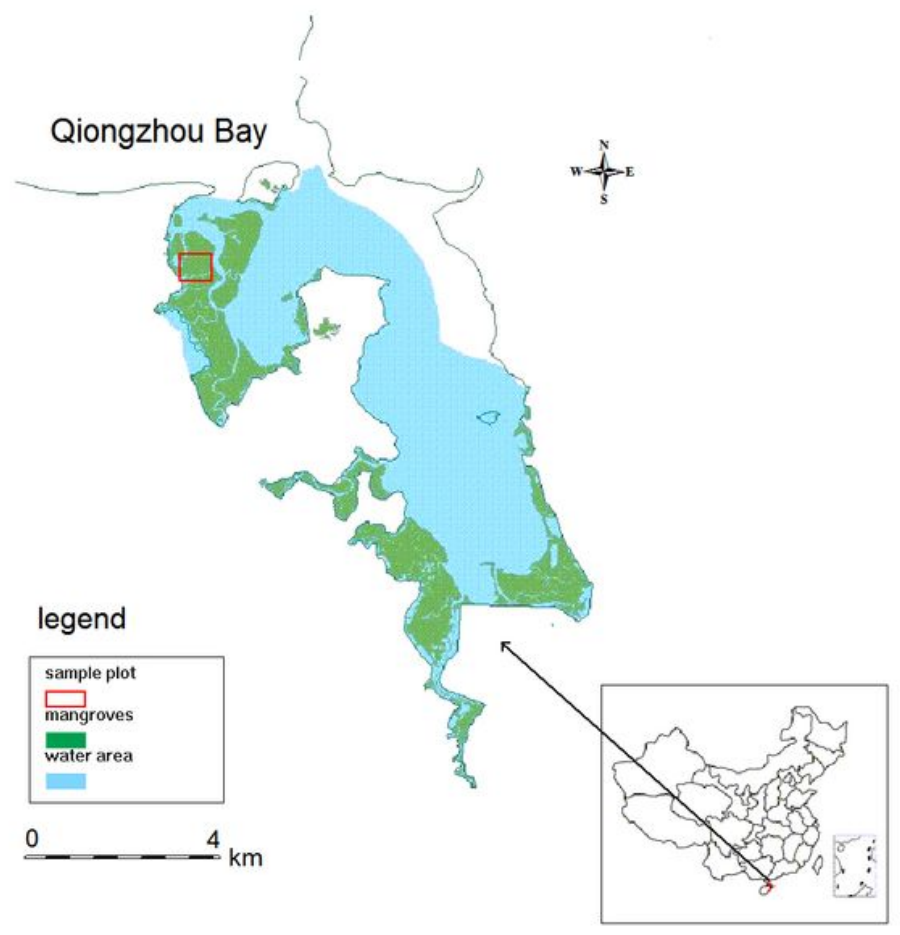

\section{Figure 1}

Map of study sample site of Dongzhaigang, Hainan, China. Note: The designations employed and the presentation of the material on this map do not imply the expression of any opinion whatsoever on the part of Research Square concerning the legal status of any country, territory, city or area or of its authorities, or concerning the delimitation of its frontiers or boundaries. This map has been provided by the authors. 

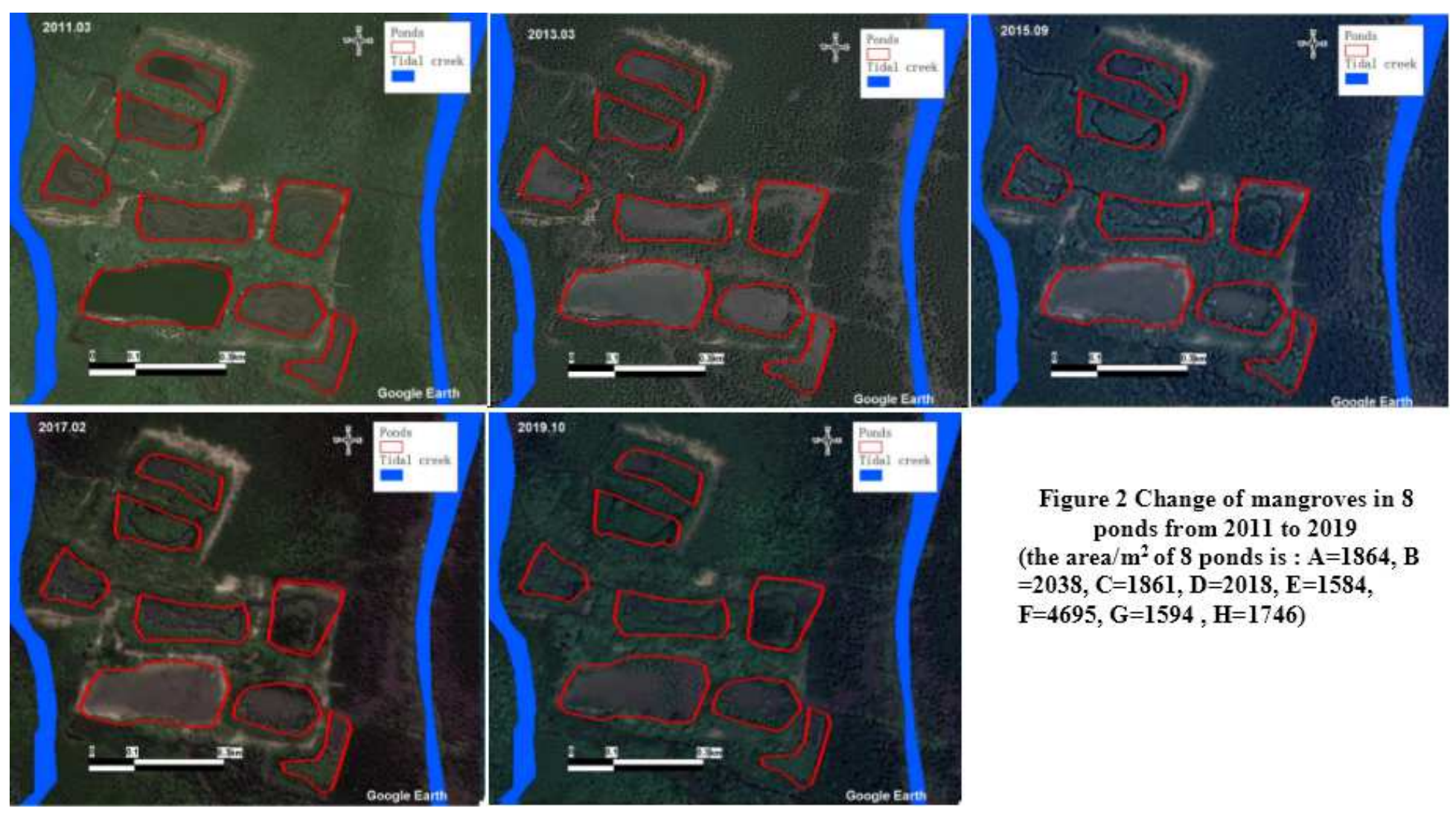

Figure 2 Change of mangroves in 8 ponds from 2011 to 2019

(the area/ $\mathrm{m}^{2}$ of 8 ponds is : $A=1864, B$ =2038, $\mathrm{C}=1861, \mathrm{D}=2018, \mathrm{E}=1584$,

$F=4695, G=1594, H=1746$ )

Figure 2

Change of mangroves in 8 ponds from 2011 to 2019 (the area/m2 of 8 ponds is : $A=1864, B=2038$, $C=1861, D=2018, E=1584, F=4695, G=1594, H=1746$ ) 


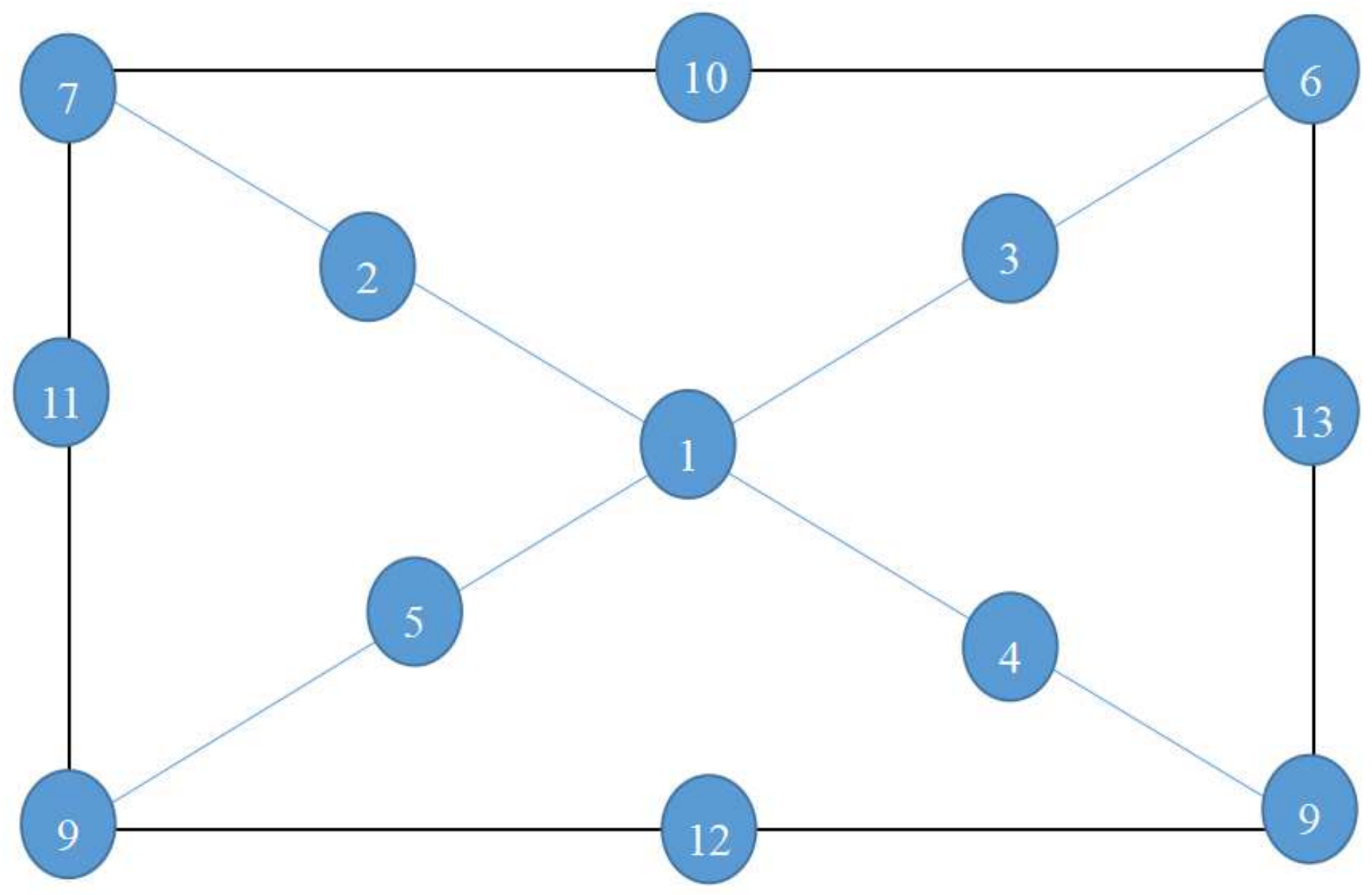

Figure 3

Elevation measure points within each pond

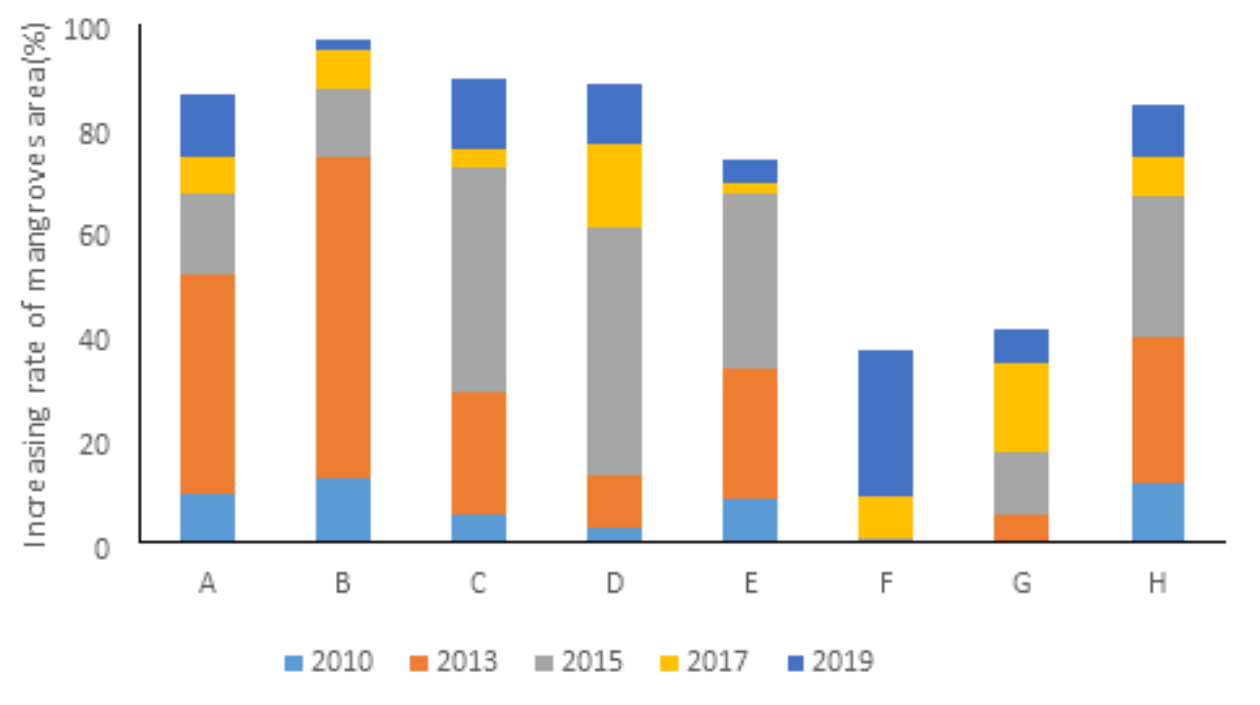

Figure 4

Increasing rate of mangroves area within each pond in the study site 


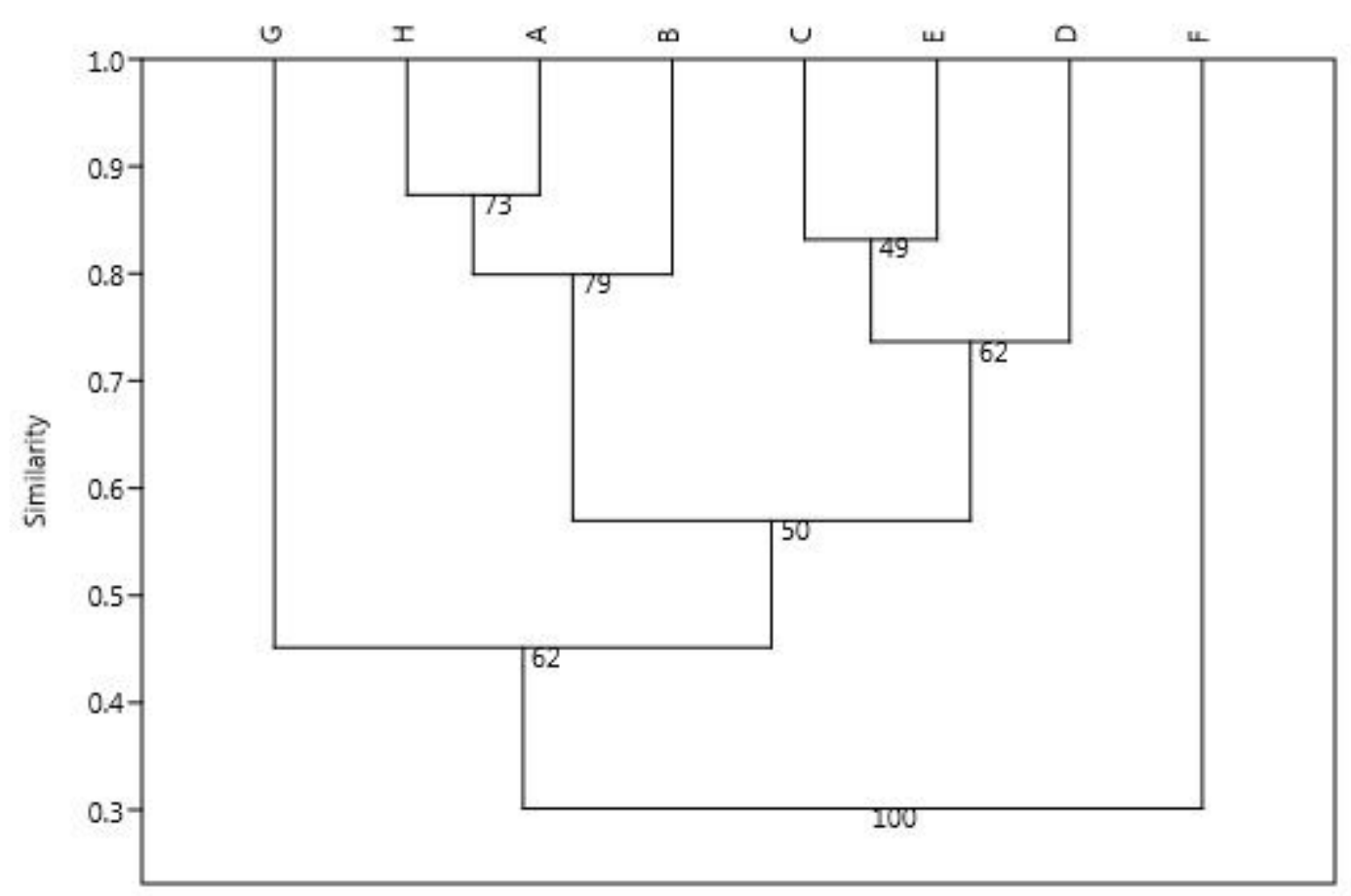

Figure 5

Similarities of mangrove species composition within 8 ponds using Hierarchal Clustering Analyse 

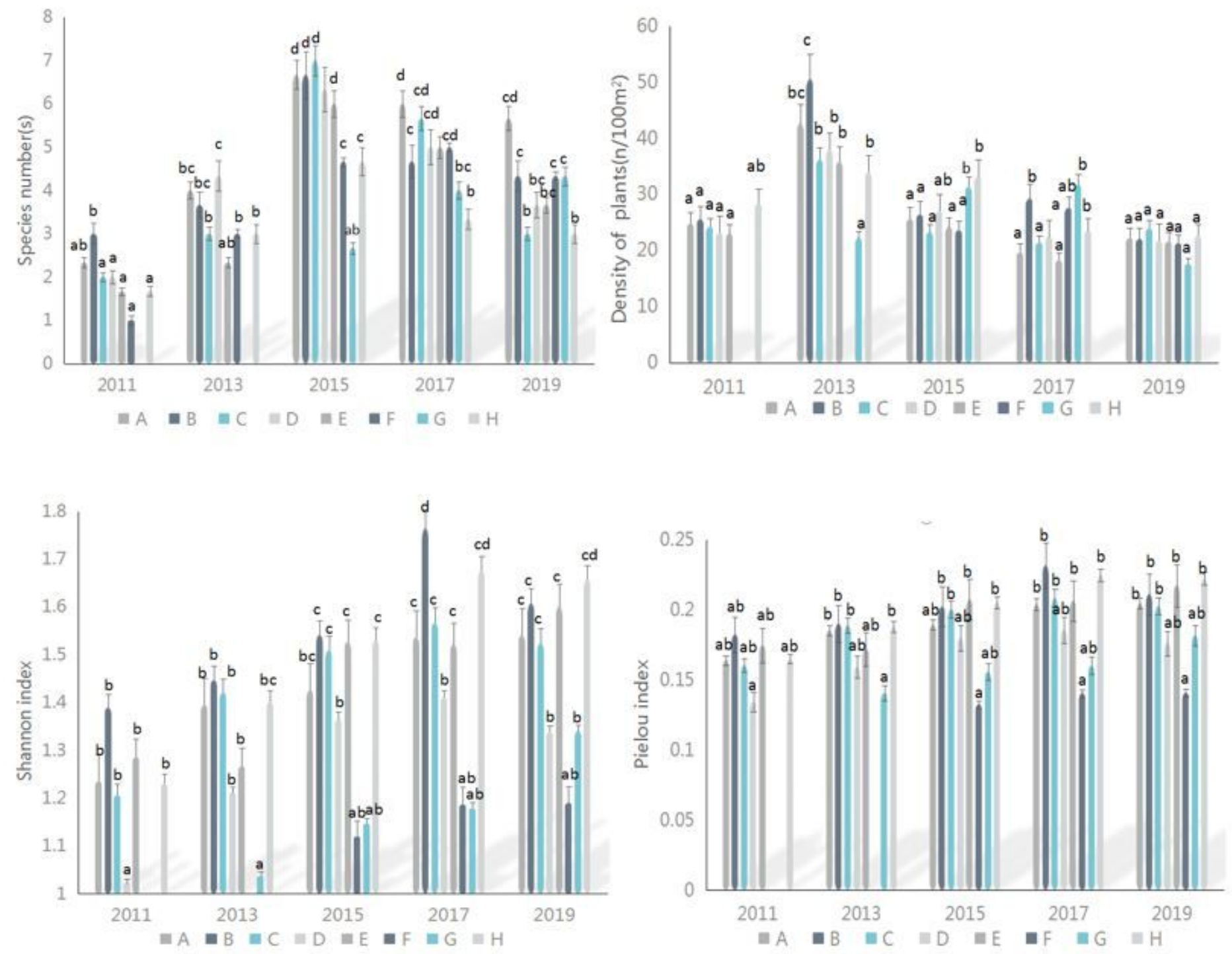

Figure 6

Community structure index within 8 ponds in different year (different letters on the top of bars mean significant difference $(P<0.05)$, and same letters mean no significant difference $(p>0.05))$ 


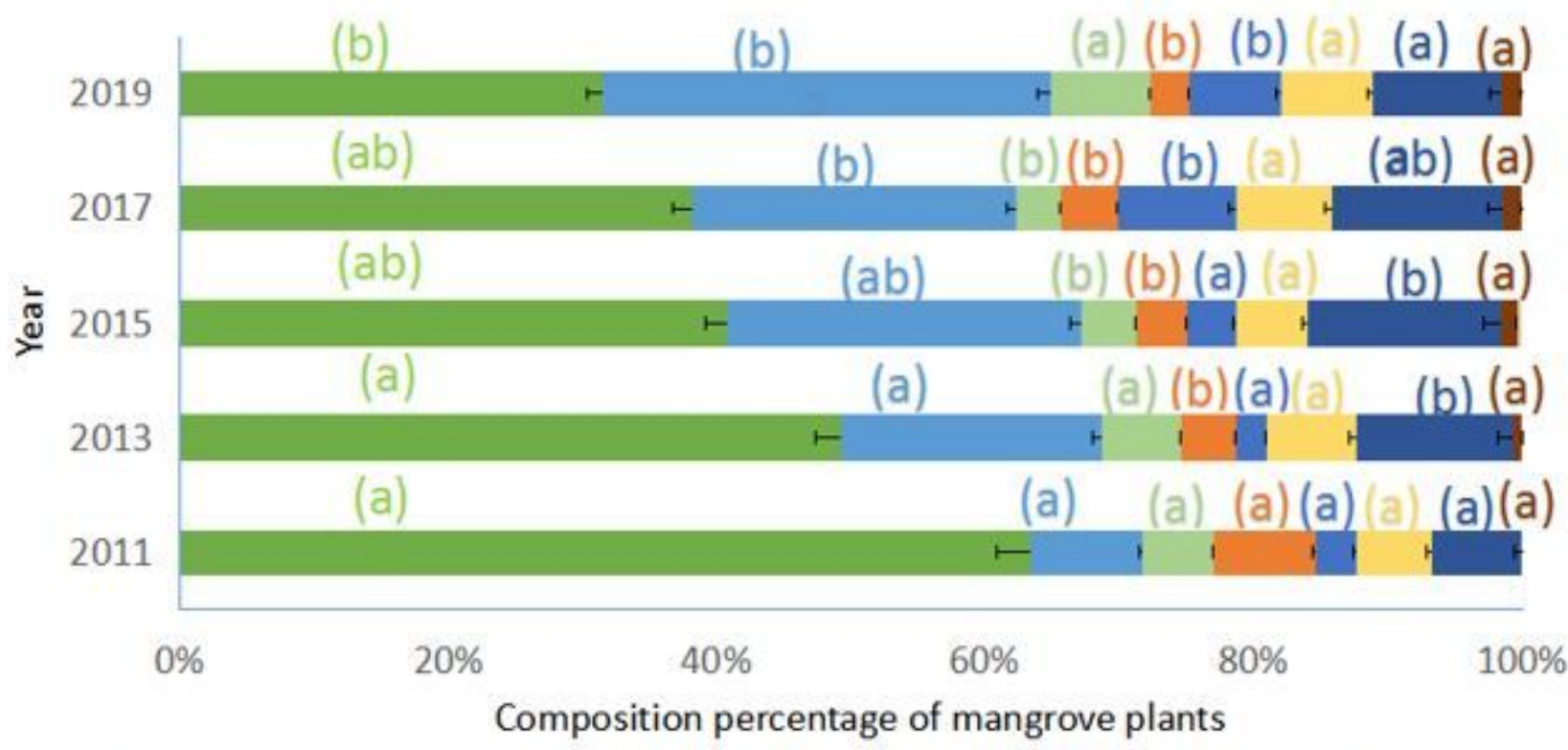
A.corniculatum R.stylosa
B.sexangula
B.gymnoihiza
K. obovata
A.marina
S.apetala
A.ilicifolius
Ceriops tagal
L.racemosa

\section{Figure 7}

Percentage of mangrove species composition in different regeneration years 